\title{
メソ気象モデルによる数値シミュレーション に基づいた降雨-地形関係の解析 \\ STUDY ON RELATIONSHIP BETWEEN RAINFALL AND TOPOGRAPHY ON THE BASIS OF NUMERICAL SIMULATIONS USING A MESOSCALE METEOROLOGICAL MODEL
}

\author{
鈴木 善晴 1 ・宮田 昇平 ${ }^{2} \cdot$ 中北 英一 ${ }^{3}$ ・池淵 周一 4 \\ Yoshiharu SUZUKI, Shohei MIYATA, Eiichi NAKAKITA and Shuichi IKEBUCHI \\ ${ }^{1}$ 正会員 工修 宇都宮大学助手 工学部建設学科建設工学講座 ( T 321-8585 宇都宮市陽東 7-1-2) \\ 2学生員 京都大学大学院 工学研究科環境地球工学専攻 ( $=606-8501$ 京都市左京区吉田本町) \\ ${ }^{3}$ 正会員 工博 京都大学大学院助教授 工学研究科環境地球工学専攻 ( $\bar{T}$ 606-8501 京都市左京区吉田本町) \\ 4フェロー工博 京都大学教授 防災研究所水資源研究センター (T 611-0011 宇治市五ヶ庄)
}

\begin{abstract}
Rainfall-topography relationship was analyzed by running numerical simulations using the MM5, which is the mesoscale model constructed in the Pennsylvania State University and National Center for Atmospheric Research (PSU-NCAR). For a quantitative estimation of topographic effect on rainfall distribution, the Dependence Line on Topographic Elevation (DLTE), one of the models which represent rainfall-topography relationship, were simulated and analyzed in four regions in Japan. The properties of DLTE and the requirements for establishing the relation of DLTE were determined in each region. Next, the influence of the scale of topography on rainfall-tonngraphy relationship was investigated by running simulations under the conditions where the resolution of topography has various scales. It was found that the relation between the scale of topography and the degree of topographic effect differs from region to region, and that the degree depends largely on the scale of mountains in a region.
\end{abstract}

Key Words : rainfall-topography relationship, rainfall distribution, topographic elevation, mesoscale meteorological model, numerical simulation

\section{1. 序論}

\section{(1) 研究の背景と目的}

我が国の山岳域ような複雑な地形条件を持つ地域に おいては，地形の影響による非線形効果が増大し，日々 の天候を決定づけるメソスケールの大気現象が非常に 複雑な挙動を示すため, 雨域の短時間予測や降雨の分 布特性解明が非常に困難なものとなっている。しがしな がら，豪雨災害に対する適切な防災対策や効率的な水 資源計画を立てるためには，さまざまな時空間スケー ルにおける降雨分布の確率構造の解明が必要であり，長 年, 水文学および気象学上の重要課題の一つとなって いる，そこで，本論文では，降雨の物理的・確率的分 布構造モデルの構築を目指して，メソ気象モデル MM5 を用いた数值シミュレーションに基づいた，山岳域に おける降雨-地形関係の解明を試みる.

大気現象に影響を与えていると考えられる地形因子 としては地形標高や斜面勾配, 斜面の向き, 谷の開放 度, 海岸距離など様々なものが考えられる. 従来の研 究においても, 複数の地上雨量計による観測值に基づ いて，これらの地形因子を説明変数とした降雨分布と
地形特性との相関分析が行われ，地域によっては雨量 の多寡が地形特性によってよく説明されることが明ら かとなっている1),2),3),4). しかしながら, 本論文では特 に地形標高に着目して解析を行う。なぜなら, 本論文

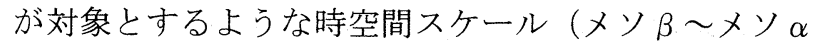
スケール）においては，降雨分布に対する様々な地形 効果のなかでも地形標高による影響が最も卓越してい ると考えられるためである。

降雨量と地形標高との間に明確な相関関係があるこ とは古くから指摘されている5),6),7)。ただし，山岳域の 降雨に対する観測技術の限界やメソ気象現象のもつ複 雑な内部構造のため, 降雨量と地形標高が厳密にどの ような関係にあり，そのメカニズムがどうなっている のか等は未だ明らかとなっていない. 一方, 降雨レー ダーによる観測值に基づいた著者ら ${ }^{8), 9)}$ の解析によれ ば，およそメソ $\beta$ スケール以上の降雨分布を対象とし た場合には, 地形標高と積算降雨量の層別平均值の間 に片対数グラフ上で明確な直線関係が成立する, すな わち両者は指数関数的な関係にあることが明らかとなっ た，著者らはこれを「降雨分布の標高依存直線」と呼 び，その特性について解析を行っている. 同直線は領域 


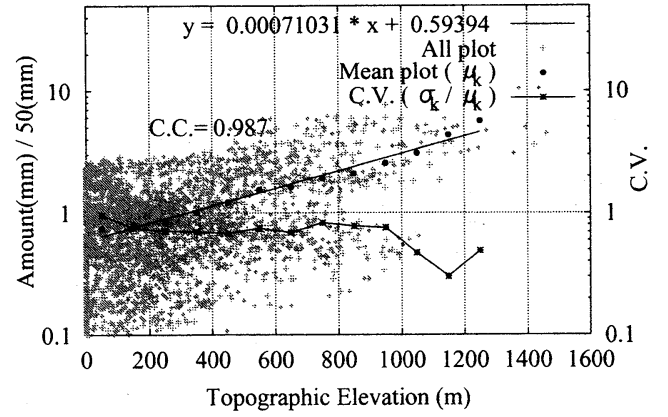

図-1 深山レーダ雨量計による観測値に基づいた積算降 雨量 (縦軸) と地形標高 (横軸) の関係 (観測領 域 : 半径 $120 \mathrm{~km}$ 円内, 領域平均降雨量 : $50 \mathrm{~mm}$ )

の平均的な降雨-地形関係を表し，その傾きが大きいほ ど降雨分布への地形効果が大きいと理解されるが, 現 在のところその詳細なメカニズムは明らかでない.

また近年は，数值気象モデルを用いて降雨-地形関係 のメカニズムを明らかにする試みも多く行われている 10),11),12),13)。主に単一の山岳が降雨分布に与える影響 について解析するため, 2 次元のメソ気象モデルや雲微 物理モデルを用いて，山岳の標高や斜面勾配，一般風 の強度などの様々な設定条件下で数值シミュレーション を行い，雨量の多寡やその分布を決定づける要因やそ のメカニズムなどを明らかにしている。しかしながら， 従来の研究においては，現実の降雨-地形関係が持つ物 理的・確率的特性について，その普遍性や特異性を考 慮した包括的な議論を行うまでには至っていない。

\section{（2）研究の意義と特徴}

ここで，降雨分布の標高依存直線を表したグラフを 図-1に示す．近畿地方を観測対象とする深山レーダ雨 量計による観測值をもとに，観測領域内の全地点（各 地点 $3 \mathrm{~km}$ グリッド）における積算降雨量と地形標高と の関係を片対数グラフ上で表したものである.ここで， 地形標高を適当な間隔で層別化し，各標高区分内にお ける層別平均值をプロットすると図中の黒丸で示すよ うに相関係数 0.9 以上の明確な直線関係が成立する.こ の直線関係が降雨分布の標高依存直線である.

同直線の傾きの大きさには，対象地域の地形特性や 対象とする降雨の性質がよく反映されており，同直線 は降雨-地形関係の最も基本的・本質的な特性を表して いる. 前述したように，メソスケール（特にメソ $y$ ス ケール）の降雨-地形関係は非常に複雑な挙動を示すこ とから，その普遍的特性を明らかにするためには，標 高依存直線のようなよりマクロな視点から降雨-地形関 係を明らかにすることが必要である。また一方で，ミ クロなスケールの地形効果は同直線からの雨量偏差と して現れており, 同直線周りの分散構造を解析するこ とによってその特性を明らかにすることが可能となる.

以上の背景のもと，本論文では，メソ気象モデル MM5 を用いた数值シミュレーションを行うことによって，降 雨分布の標高依存直線をべースとした降雨-地形関係の 解析を行う。

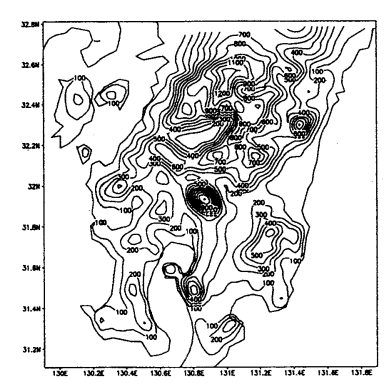

(a) Kyushu $(61 \times 61)$

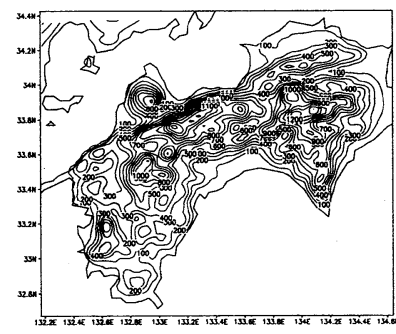

(c) Shikoku $(64 \times 76)$

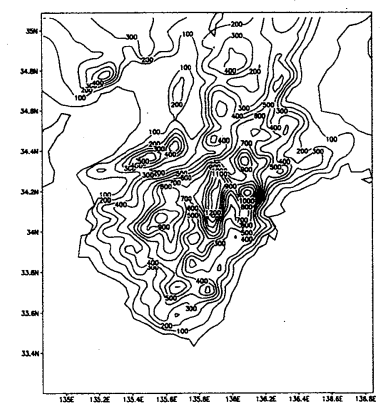

(b) Kinki $(70 \times 61)$

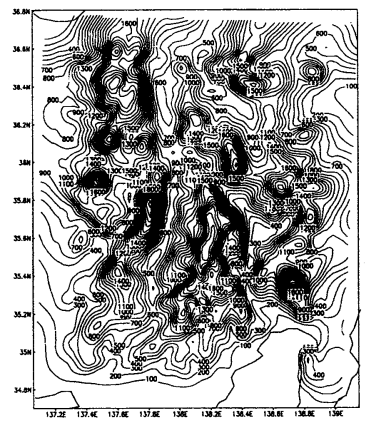

(d) Chubu $(76 \times 61)$
図-2 本論文の解析対象領域（コンターは地形標高, 数字は各領域のグリッド数 $(3 \mathrm{~km}$ グリッド $)$

\section{2. 計算条件の設定と再現精度の検証}

本論文では, NCAR (National Center for Atmospheric Research）とペンシルバニア州立大学とで共同開発され たメソ気象モデルThe Fifth-Generation NCAR / Penn State Mesoscale Model（通称 MM5）を用いてシミュ レーションを行う. MM5 では, Two-way ネスティング を用いたシミュレーションを行うことができる．ネス ティングとは，解析対象領域である fine domain (F.D.) を含むより大きなスケールの coarse domain (C.D.) で 先に計算を行い，次にその計算結果を境界条件として F.D.の計算を行うというものである. 本論文では特に, C.D. と F.D.の計算を同時に行い，全ての時間ステップ で相互に計算結果を受け渡す Two-way ネスティングを 採用した。 また，グリッドスケール $27 \mathrm{~km}, 9 \mathrm{~km}, 3 \mathrm{~km}$ の 3 つの domain (順に Domain1, Domain2, Domain3) を設定して 3 段階のネスティングを行うこととした.

本論文では，初期条件および境界条件として，GPV (Grid Point Value) データの一つである RSM 航空デー タを用いた. RSM 航空データからは, 日本時間の毎日 9 時， 21 時を初期時刻として 24 時間後までの 3 時間ご との予報值として, $80 \mathrm{~km}$ 間隔の格子状データを地上か ら対流圈界面の高さまで得ることができる. 本論文で は, ジオポテンシャル高度, 気温, 風速, 湿度の GPV データよりモデルの初期值となる内挿データを作成し た。また，側面境界条件としては，6 時間おきの GPV データを用いて線形的に空間・時間内挿したものをモデ ルに与えることとした．また，地形標高データとして は, USGS (U.S. Geological Survey) 提供の緯度・経 度 30 秒（約 $0.925 \mathrm{~km}$ ）および 2 分（約 $3.70 \mathrm{~km}$ ）の解像 

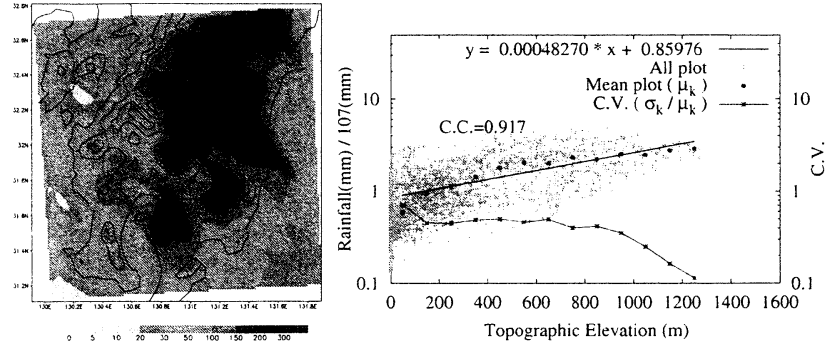

(a) Kyushu (99.7.25-26)
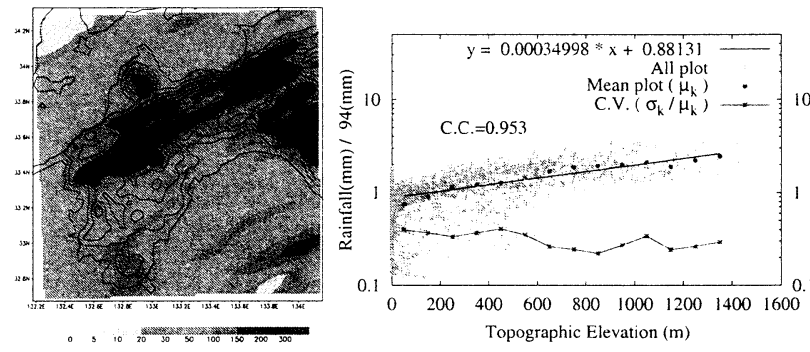

(c) Shikoku (99.6.18 - 19)
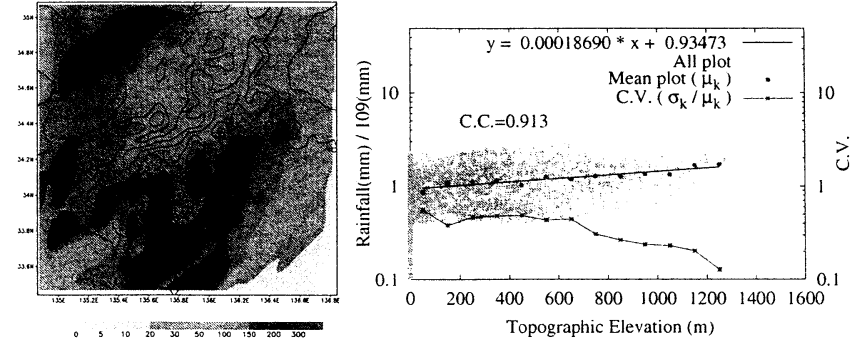

(b) Kinki (98.10.16 - 17)
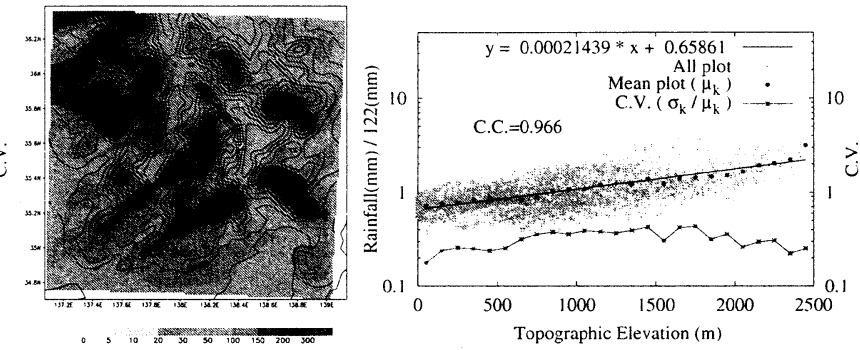

(d) Chubu (98.6.21 - 22)

図-3 シミュレーションによる 2 日積算降雨量の分布（左図，単位は $\mathrm{mm}$ ），およびその地形標高との関係（右図）

度を持つデータを用いた. Domain3 は前者, Domain1 およびDomain2 には後者のデータを適用した.

本論文では，複数の地域において行ったシミュレー ション結果を比較検討することにより，地形特性の違 いによる降雨-地形関係への影響の解明を試みる. 今回 は，我が国の山岳域の中で，九州南部，近畿南部，四 国，中部の 4 地域に着目してシミュレーションを行う こととする. 図-2 に各地域におけるDomain3（解析領 域）の設定範囲を地形標高の様子とともに示す.

また，2 日間の計算を 1 事例として，各地域 15 事例 ずつシミュレーションを行い，主に数日程度の時間ス ケール（メソ $\beta$ スケール）において降雨-地形関係の解 析を行うこととする. 1998 年および 1999 年を対象とし て，各地域ごとに比較的降雨量が多い期間を AMeDAS 観測雨量に基づいて選択した。なお，計算の時間ステッ プについては，Domain1は 81 秒，Domain2 は 27 秒, Domain3 は 9 秒と設定した。

以上の計算条件のもとで行う降雨分布のシミュレーシ ヨンがどの程度の再現精度を持っているのか, AMeDAS 観測雨量との比較により検証を行ったところ，地点雨 量など細かな視点でみると再現精度が高いとはいえな いが，多雨域の位置など領域全体の傾向としては比較 的高い精度を示していたことから，本論文の目的に対 しては十分な精度を持つものと判断した。

\section{3. 降雨分布の標高依存直線と時間積分過程}

著者ら ${ }^{8)}$,9) の解析では，降雨レーダーによる観測雨 量をもとに，近畿地方および九州南部において降雨分 布の標高依存直線の成立が確認されている。しかしな がら，同直線が，レーダーの観測誤差（グランドクラッ タなど）に起因したものではないか，また，あらゆる地 域で成立する普遍的な関係かどうかなど，確認すべき 課題が残されている。そこで本節では，同直線がモデ
ルによって再現されうるかどうかについて検証を行う.

\section{（1）モデルによる降雨分布の標高依存直線}

はじめに，2 日単位で行った各地域のシミュレーショ ン結果より, 地形標高と 2 日積算降雨量との関係を示 したグラフおよび分布図を図-3に示す.ただし, 各地 域とも解析対象をグリッド数 $60 \times 60$ の領域に限定し た。同図より，どの事例においても地形標高および積算 降雨量の層別平均值（図中の黒丸）に明確な直線関係 が成立していることがわかる，すなわち，モデルによっ て標高依存直線が再現されうることが明らかとなった。 また，複数の地域で成立する普遍性の高い特性である ことも示された。このように物理モデルによって再現 されるということは，標高依存直線が降雨分布のもつ 単なる統計的な特性ではなく, 何らかの物理的义カ二 ズムに基づいた特性であると考えられる。

さらに, 標高依存直線の傾きについて, 近畿地方に 位置する深山レーダ雨量計の観測雨量から求めた值と の比較を行った結果が 図-4である. 同直線の傾きは降 雨分布に対する地形効果の大きさを表すと理解される が，同図より，いくつかの事例を除けばシミュレーショ ンと観測の両者が非常によい対応を示していることが 分かる.このことは, モデルによる降雨域・降雨量の 再現精度がそれほど高くなくとも，標高依存直線とい うマクロな降雨-地形関係は，モデルによって十分よい 精度で再現されることを意味している。

著者ら $\left.{ }^{8)}, 9\right)$ によれば，標高依存直線の成立条件の一 つは, 対象領域内の領域平均降雨量が $50 \mathrm{~mm} \sim 100 \mathrm{~mm}$ 以上となることである. そこで，モデルで再現された標 高依存直線に対しても同様のことが言えるかどうか調 查を行う。ただし，ここでは（標高依存直線に対する） 積算降雨量の層別平均值（図中の黒丸）の RMSE（平 均二乗誤差平方根）をその判断基準として用いる。様々 なケースに対して RMSE を計算した結果から「RMSE 


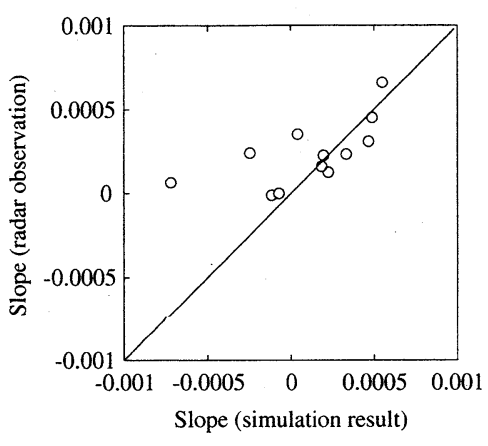

図-4 シミュレーションおよび深山レーダ雨量計の観測 雨量に基づいた標高依存直線の傾き（近畿地方）

の值が 0.1 以下のとき標高依存直線が成立していると みなすことができる」と判断した。

各地域 15 事例の降雨分布を対象として RMSE の值 を計算し，その值が成立条件を満たす割合を領域平均 降雨量に対して求めた結果が図-5 である，同図を見る と, 標高依存直線の成立割合が 8 割から 9 割程度に達 する領域平均降雨量には地域差が生じており, 同直線 の成立条件が地域によって異なることが分かる．ただ し, 領域平均降雨量が $100 \mathrm{~mm}$ 以上であれば, どの地域 においてもほとんどのケースで同直線が成立しており， 従来の解析とほぼ一致する結果となった.

\section{（2）モデルによる降雨分布の時間積分過程}

著者ら ${ }^{8), 9)}$ によれば，降雨の分布特性はその積分時 間スケールに依存しており，降雨-地形関係を明らかに するためには「降雨分布の時間積分過程」に着目する ことが必要である。同過程は，図-6 の概念図に示すよ うに，積分時間スケールを 3 つのステージに分けて説 明することができる.

第 1 ステージ（メソ $y$ スケール程度）では，降雨分 布の変動が激しいために標高依存直線が成立せず，降 雨分布に対する普遍的な地形効果を見いだすことはで きないが，第 2 ステージ（メソ $\beta$ スケール程度）にな ると, 依然として降雨分布の変動は大きいものの標高 依存直線が成立し，降雨分布に対する地形効果が発現 する. さらに，第 3 ステージ（メソ $\alpha$ スケール程度）で は，標高依存直線周りの降雨分布のばらつきが小さく なりほぼ一定值に収束することによって, 明確な地形 効果が発現するようになる.このとき, 領域平均降雨 量の值が積分時間スケールをおよそ代表していると考 えると，第 1 の境界となる積分スケールは，標高依存 直線の成立条件に着目することにより領域平均降雨量 $50 \mathrm{~mm} \sim 100 \mathrm{~mm}$ 程度（既述），また第 2 境界スケール は，標高依存直線周りの変動係数に着目することによ り同 $200 \mathrm{~mm} \sim 250 \mathrm{~mm}$ 程度となることが分かっている. このように, 降雨の分布特性は積分スケールによって 異なった特性を示すと考えることができる.

ここで，第 2 境界スケールについて，シミュレーショ ン結果に基づいた解析を行うため，モデルによる降雨 分布に対して標高依存直線まわりの変動係数を求め, そ の領域平均降雨量に対する推移の様子を示したものが

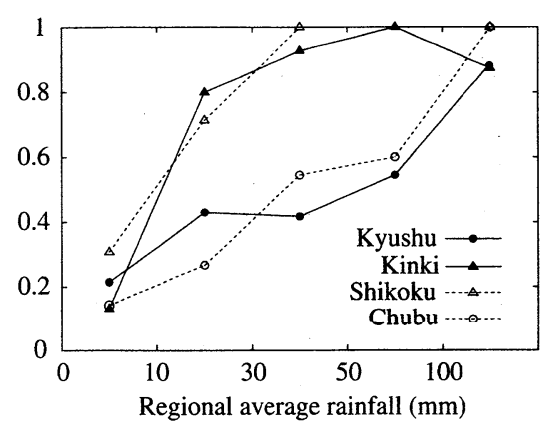

図-5 標高依存直線に対する RMSE が 0.1 以下になる 割合と領域平均降雨量の関係

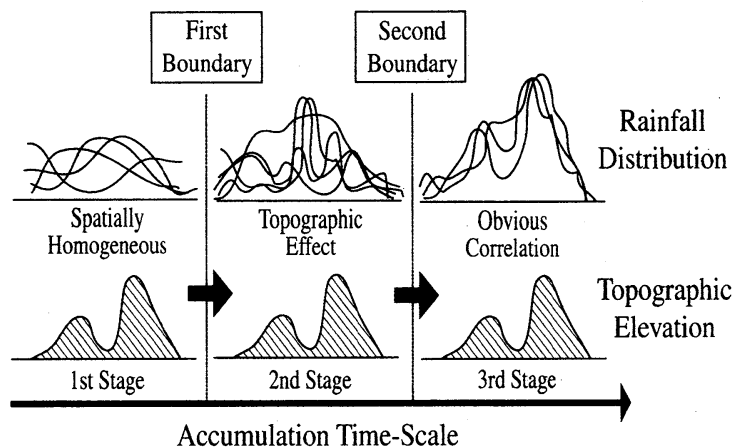

図-6 降雨分布の時間積分過程の概念図

図-7である．同図より，どの事例においても次第に変 動係数の值が減少し, やがてほぼ一定值に収束する様 子が見て取れる. 収束時の積分スケール（第 2 境界ス ケール）や，収束後の変動の大きさなどが地域によって また事例によって異なるものの, 時間積分過程として は上記と同様な傾向を示すことが見て取れる.すなわ ち, モデルによる降雨分布においても, 時間積分過程 の概念が成立することを確認することができた.

\section{4. 地形の空間スケールと降雨-地形関係}

本節では，時間積分過程の第 3 ステージにおける降 雨-地形関係に着目して解析を行う。同ステージにおい ては, 降雨-地形関係からメソ $\gamma$ スケールの変動要素が 十分排除され, その結果, メソ $\beta$ スケール程度のマク 口な降雨-地形関係の特徵が最もよく表れていると考え ることができる. 一方, 降雨-地形関係の解析では, こ のような時間スケールだけでなく, さまざまな空間ス ケールもまた重要な意味を持つ. そこで本節では，特 に「地形の空間スケール」に着目して, その降雨-地形 関係に与える影響について考察する。

\section{（1）地形解像スケールが降雨-地形関係に与える影響}

はじめに，解像スケールが異なる複数の地形条件を 導入したシミュレーションを行い,「地形解像スケール」 が降雨-地形関係に与える影響について解析を行う。解 像スケール $3 \mathrm{~km}$ の地形の他に，解像スケール $9 \mathrm{~km}$ およ び $27 \mathrm{~km}$ の地形を用いて, 各事例それぞれ 3 ケースの シミュレーションを行った（以下，各ケースをTopo3, 


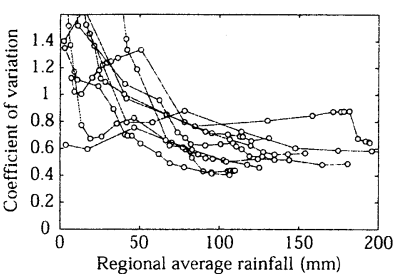

(a) Kyushu

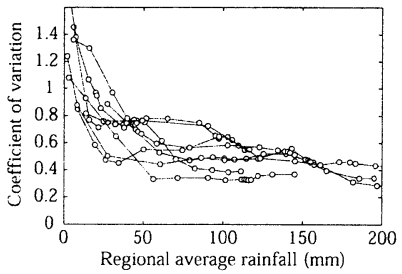

(c) Shikoku

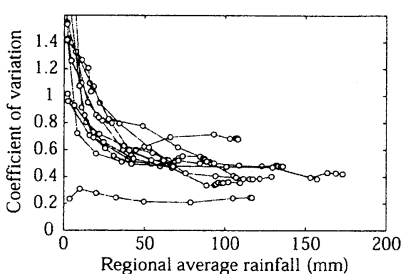

(b) Kinki

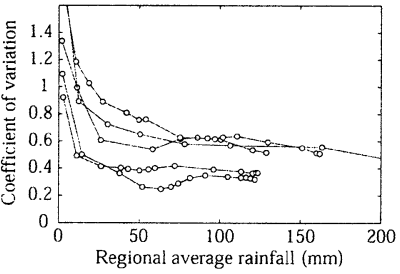

(d) Chubu
図-7 標高依存直線まわりの変動係数の推移（各地域 15 事例のうち 2 日積算後の領域平均降雨量が $100 \mathrm{~mm}$ 以上の事例のみ)

Topo9 などと記す）。なお，モデルの計算グリッドス ケール（Domain 3 は $3 \mathrm{~km}$ ）など, 地形標高データ以外 の設定については前節までと全く同様である.

シミュレーションによる 2 日積算降雨量の分布, およ びその地形標高との関係を 図-8 に示す。ここでは一例 として近畿南部のケースを示した。同左図からは，地 形解像スケールが大きくなるとともに，次第に地形標 高が平滑化されていく様子が見て取れる．またそれに 伴って，降雨分布における細かな空間変動が少なくな り，全体的に滑らかな分布を示すようになる．ただし， 雨域の位置や降雨強度などの傾向には大きな変化は見 られない, 一方, 同右図に示した標高依存直線に着目 すると, その傾きに大きな変化はないものの, 同直線 周りのばらつきについては若干の変化が見て取れる.

ここで, 図-7 と同様に変動係数の推移を調査したと ころ図-9 に示す結果となった。同図を見ると，変動係 数が収束する積分スケールには地形解像スケールによ る影響はあまりないが, 収束後の変動の大きさにはど の地域でも変化が生じている. 九州南部および近畿南 部では Topo 27 で最も変動が大きいのに対し，四国およ び中部では逆に最も小さくなっている，ただし，変動 の大きさ自体は全体的に前者の方が大きい. ここでさ らに，解像スケール $56 \mathrm{~km}$ の地形（Topo56）を用いて 同様にシミュレーションを行ったところ, どの地域に おいても Topo 27 より変動が大きくなった。すなわち, 降雨-地形関係の空間変動の大きさは, 地形解像スケ一 ルによって図-10 のような変化を示すことが分かる.

\section{(2) 山岳スケールが降雨-地形関係に与える影響}

次に,このような地域差が生じる原因について考察 する，九州南部および近畿南部では，図-8 からもわか るように（ただし図は後者のみ），Topo27の地形標高 が全体的に小さくなり, 最高標高が $1000 \mathrm{~m}$ 程度である. これは，これらの地域における「山岳のスケール」が小 さいために, Topo27 では多くの山岳が平滑化されたこ
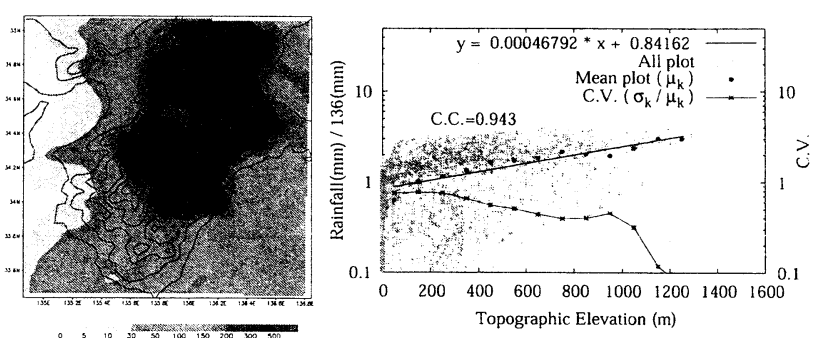

(a) Topo3 (resolution scale of topography : $3 \mathrm{~km}$ )
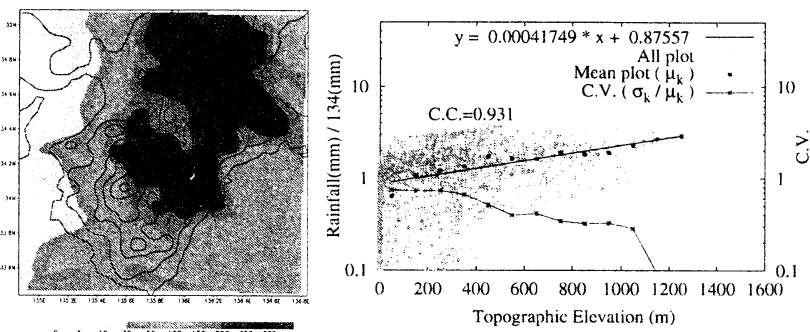

(b) Topo9 (resolution scale of topography : $9 \mathrm{~km}$ )
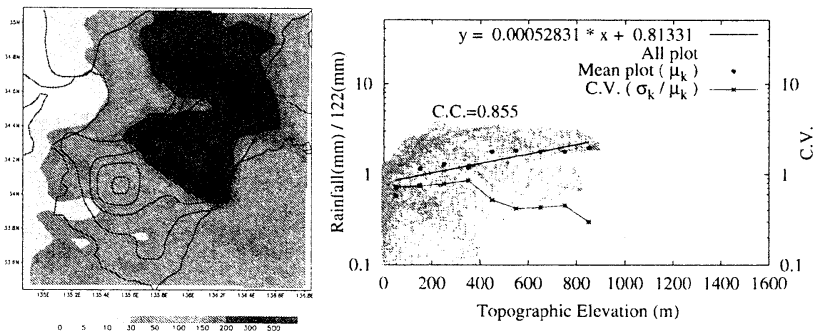

(c) Topo27 (resolution scale of topography : $27 \mathrm{~km}$ )

図-8 解像スケールの異なる地形を用いたシミュレーション による 2 日積算降雨量の分布（左図）およびその地形 標高との関係（右図）（近畿南部，98.9.15～16）

とを意味している．ただし，ここで述べる「山岳のス ケール」とは単に標高の高低だけではなく，単峰性や 連峰性などの空間的広がりをもつスケールを考えてい る。すなわち，これらの地域における地形効果は，ス ケールの比較的小さな山岳に起因するものであったが, Topo27 では領域内の山岳の多くが平滑化されたため降 雨分布に対する地形効果が小さくなり, その結果, 降 雨-地形関係の空間変動が大きくなったと考えられる. 言い換えると, 同地域では解像スケール $3 \mathrm{~km}$ またはそ れ以下で表現されるスケールの小さい地形による影響 が卓越しており，降雨-地形関係の空間変動の大きさは， 図-10の概念図にも示したように，その程度の地形解 像スケールにおいて最も小さくなると思われる.

一方，四国および中部の Topo 27 では，平滑化によっ て標高はある程度小さくなったものの，九州南部・近 畿南部ほどは平滑化されていない(図は省略)。このこ とは，これらの地域における山岳スケールが比較的大 きいことを意味している。したがって，同地域の地形 効果には，大小様々なスケールの地形による影響が含 まれていると考えることができる．ここで，図-10に 示したように，起伏の激しい小さなスケールの地形を 含むTopo3 やTopo9 のケースよりも，それらが除去さ れたTopo27のケースの方がより変動が小さくなったこ とに着目すると，同地域では，比較的スケールの大き 


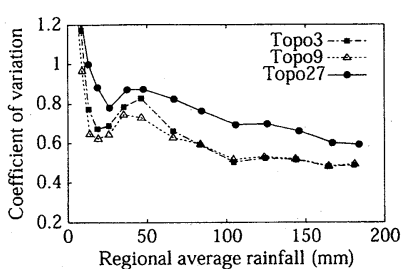

(a) Kyushu (99.7.2 - 3)

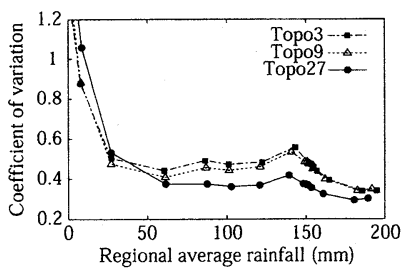

(c) Shikoku (98.10.16 - 17)

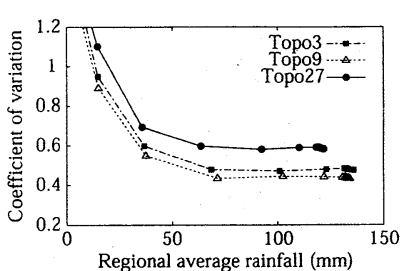

(b) Kinki $(98.9 .15$ - 16)

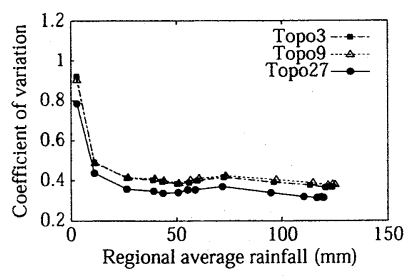

(d) Chubu (98.6.13 - 14)
図-9 解像スケールの異なる地形を用いたシミュレーショ ンによる標高依存直線まわりの変動係数の推移

な山岳による地形効果が卓越しており，スケールの小 さな地形は主に変動を増大させるノイズとして働いて いると思われる．また，Topo56のケースでは，さらに スケールの大きな山岳までが平滑化の影響を受けるた め降雨分布に対する地形効果が小さくなり，一転して 変動が大きくなったと考えられる.

このように，降雨-地形関係においては，領域の山岳 スケールがどの程度のスケールであるかが非常に重要 な要素であり，そのスケールの大小によっては，同じ スケールの地形であっても降雨分布に対して異なった 影響を及ぼすことが明らかとなった．ただし，本論文 では主にメソ $\beta$ スケールの降雨-地形関係を対象とした が，他の時空間スケールを対象とした場合には，地域 によって上記とはまた異なったスケールの地形が卓越 した影響力を持つと考えられる。したがって，普遍的 な降雨-地形関係を明らかにするためには，このような 降雨分布の時空閒スケールや地形の空閒スケールを考 慮することにより，地域特性によって変化する降雨-地 形関係の本質をまず見極めることが重要であろう.

\section{5. 結論}

以上, 本論文では, 降雨の物理的・確率的分布構造モ デルの構築を目指して, 数值シミュレーションに基づ いた山岳域における降雨-地形関係の解析を行った. 本 論文で得られた成果は以下の通りである.

はじめに，モデルによって再現された日本の複数地 域の降雨分布において, 標高依存直線および時間積分 過程の概念が成立することを確認するとともに, 降雨地形関係が地域によってどのように異なるかを明らか にした。 また, 対象地域における山岳スケールの大小 によって, 同じ解像スケールの地形であっても降雨分布 に対して異なった影響を及ぼすことを明らかにし，地 形の空間スケールが降雨-地形関係における重要な要素 の一つであることを示すことができた

今後は, さらに多くの事例に対してシミュレーション

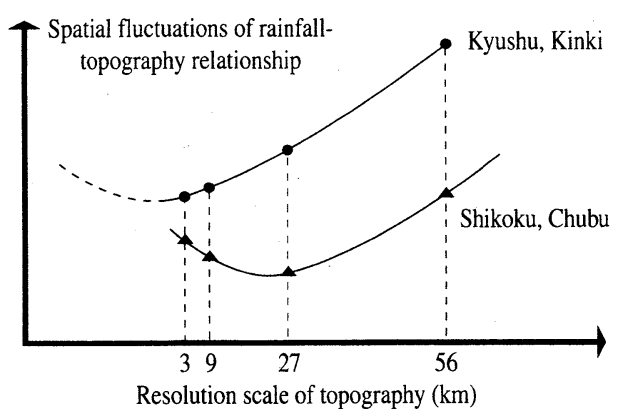

図-10 降雨-地形関係の空間変動量と地形解像スケール との関係を表した概念図

を行い，統計的な観点から降雨-地形関係を明らかにす るとともに，仮想条件を用いたシミュレーションによ る同関係のメカニズム解明に取り組む予定である.

\section{参考文献}

1) Spreen, W. C.: A determination of the effect of topography upon precipitation, Trans. Am. Geophys. Union, Vol.28, pp.285-290, 1947.

2) Burns, J. I.: Small-scale topographic effects on precipitation distribution in San Dimas Experimental Forest, Trans. Am. Geophys. Union, Vol.34, pp.761-768, 1953.

3) Linsley, R. K.: Correlation of rainfall intensity and topography in northern California, Trans. Am. Geophys. Union, Vol.39, pp.15-18, 1958.

4) Williams, P. and Peck, E. L.: Terrain influences on precipitation in the intermountain west as related to synoptic situations, J. Appl. Meteor., Vol.1, pp.343-347, 1962.

5) Lee, C. H.: Precipitation and altitude in the Sierra, Mon. Wea. Rev., Vol.39, pp.1092-1099, 1911.

6) Alter, J. C.: Normal precipitation in Utah, Mon. Wea. Rev., Vol.47, pp.633-636, 1919.

7) Henry, A. J.: Increase of precipitation with altitude, Mon. Wea. Rev., Vol.17, pp.33-41, 1919.

8）鈴木善晴・中北英一・池淵周一: 標高依存直線に基づいた 降雨分布の地形依存特性の解明, 水工学論文集, 第 45 巻, pp.301-306, 2001.

9）鈴木善晴・諸橋真琴・中北英一・池淵周一: 3 次元構造お よび降雨タイプを考慮した降雨分布の地形依存特性の解 析, 水工学論文集, 第 46 巻, pp.13-18, 2002.

10) Colton, D. E.: Numerical simulation of the orographically induced precipitation distribution for use in hydrologic analysis, J. Appl. Meteor., Vol.15, pp.12411251, 1976.

11) Alpert, P.: Mesoscale indexing of the distribution of orographic precipitation over high mountains, J. Clim. Appl. Meteor., Vol.25, pp.532-545, 1986.

12) Barros, A. P. and Lettenmaier, D. P.: Dynamic modeling of orographically induced precipitation, Rev. Geophys., Vol.32, pp.265-284, 1994.

13）大石哲・木谷有吾 $\cdot$ 中北英一・池淵周一: 豪雨の生起 $\cdot$ 発 達に地形が及ぼす影響に関する数值実験的研究，京都大 学防災研究所年報, 第 39 号/B-2, pp.1-20, 1996.

(2002. 9. 30受付） 